\title{
Effects of exogenous nitric oxide on cadmium toxicity and antioxidative system in perennial ryegrass
}

\author{
Chen, Weifeng ${ }^{1}$, Dong, Yuanjie $^{1^{*}}, \mathrm{Hu}$, Guoqin $^{1}$, Bai, Xiaoying $^{1}$ \\ ${ }^{1}$ College of Resources and Environment, National Engineering Laboratory for Efficient Utilization of Soil and \\ Fertilizer, Shandong Agricultural University, Tai'an, 271018, Shandong Province, China. \\ *Corresponding author:yuanjiedong@163.com
}

\begin{abstract}
The effects of sodium nitroprusside (SNP, a donor of NO) on cadmium (Cd) toxicity in ryegrass seedlings (Lolium perenne L.) were studied. 100 and $150 \mu \mathrm{M}$ Cd stress had a detrimental effect on ryegrass seedlings. Exposure of 100 and $150 \mu \mathrm{M} \mathrm{Cd}$ inhibited plant growth, decreased chlorophyll concentration, and reduced the absorption of $\mathrm{Fe}, \mathrm{Cu}$ and $\mathrm{Zn}$. Excess $\mathrm{Cd}$ also altered the activities of antioxidant enzymes, and increased the accumulation of reactive oxygen species (ROS). Exogenous NO alleviated Cd toxicity of ryegrass plants, especially under the stress of $150 \mu \mathrm{M} \mathrm{Cd}$, as evidenced by improved plant growth and increased concentrations of chlorophyll and mineral nutrients. Exogenous NO also mitigated oxidative stress by regulating the activities of antioxidant enzymes and the contents of non-antioxidants. Moreover, the absorption of $\mathrm{Fe}, \mathrm{Cu}$ and $\mathrm{Zn}$ was increased, indicating that exogenous $\mathrm{NO}$ stimulated $\mathrm{H}^{+}$-ATPase activity to promote sequestration or uptake of ions. The applications of $\mathrm{NO}$ also reduced the translocation of $\mathrm{Cd}$ from roots to the leaves. These results indicate that the mechanisms of $\mathrm{NO}$ for mitigating Cd toxicity may be associated with reduced root-to-shoot translocation of $\mathrm{Cd}$ and enhanced capacity of antioxidative systems to protect plants from oxidative stress.
\end{abstract}

Keywords: Ryegrass, cadmium, sodium nitroprusside, antioxidative systems, phytochelatins, glutathione, ion accumulation

\section{Introduction}

Cadmium $(\mathrm{Cd})$ is a widespread heavy metal pollutant that is extremely toxic to both plants and animals $(\mathrm{Xu}$ et al., 2011, Retamal-Salgado et al., 2017). It is released into the environment by heating systems, metallurgic industries, waste incinerators, urban traffic, cement factories, and as a contaminant of phosphate fertilizers (Gallego et al., 2012). Although Cd is not essential for plant nutrition, it can be easily taken up by roots and accumulated in all plant tissues, from roots to the above-ground organs (Tezotto et al., 2012). The main symptoms of Cd-induced toxicity in plants are stunted growth, chlorosis, leaf epinasty, 
altered chloroplast ultrastructure, photosynthesis inhibition, inactivation of enzymes in $\mathrm{CO}_{2}$ fixation, induced lipid peroxidation, disturbance of the nitrogen (N) and sulfur (S) metabolism (Gill and Tuteja, 2011). At a cellular level, Cd toxicity enhanced oxidative stress by increasing levels of reactive oxygen species (ROS) such as the $\mathrm{O}_{2}^{-}$, hydroxyl. Furthermore, the increased ROS production induced by $\mathrm{Cd}$ can trigger lipid peroxidation, DNA damage and oxidative modifications of proteins, which can eventually lead to cellular dysfunction and necrotic cell death (Valko et al. ,2007).

However, plants in response to $\mathrm{Cd}$ stress are manifested by the activation of various strategies to cope with its toxicity. Plant cells are normally protected against oxidative damage by a broad spectrum of radical-scavenger systems (Wang et al., 2013). To avoid $\mathrm{Cd}$ toxicity plants also has developed other mechanisms for $\mathrm{Cd}$ tolerance, which includes cell wall binding, chelation with phytochelatins (PCs), Cd compartmentation in vacuole, or enrichment in leaf trichomes (Verbruggen et al., 2009). Earlier studies showed that the vacuole is the site for the accumulation of a number of heavy metals, including Cd (De, 2000), which acts as the subdominant site of preferential Cd binding in all test tissues. Other detoxification mechanisms that plants have developed to cope with damages caused by $\mathrm{Cd}$ are related to some stress signaling molecules, such as nitric oxide (NO) and salicylic acid.

NO is an important gaseous molecule, serving as important secondary messengers in plant response to various biotic and abiotic stresses. Since the discovery in 1998 that NO has a role in plants, its functions in plant development, metabolism and disease responses have been extensively studied. Processes were shown to be regulated by NO include seed germination, root growth, respiration, stomatal closure and adaptive responses to biotic and abiotic stresses (Moreau et al.,
2010). However, the effects of NO on different types of cells have been proved to be either protective or toxic, depending on the concentration and location of NO in plant cells (Lamattina et al. 2003). Saxena et al. (2013) indicated that preservation of suitable ROS levels enhanced under metal stress might correspond to survival response and NO interacts with ROS in different ways and serves as an antioxidant during various stresses. Two interrelated mechanisms by which NO may abate stress have been proposed. First, NO may function as an antioxidant, directly scavenging the ROS that is generated by most of the stressors (Hsu and Kao, 2004). Second, NO may function as a signaling molecule in plant stress responses, leading to alterations of antioxidative gene expression (Wendehenne et al., 2001). Although several lines of evidence have highlighted the role of NO in the modulation of Cd-induced growth inhibition in perennial ryegrass (Wang et al., 2013), but exactly how NO alleviates plant growth in intact plants exposed to heavy metals is still not yet known.

Perennial ryegrass, an important forage grass and cool-season turfgrass, is known for its rapid establishment rate and good wear tolerance (Xiong et al., 2009). It is widely used for livestock, fiber products, improving soil contaminated with heavy metal, habitats for wildlife populations, recreation, and beautification. It can accumulate metals in its biomass, and commonly used as a suitable species for revegetation of metalliferous wastes (Arienzo et al., 2004). Our previous studies showed that most $\mathrm{Cd}$ accumulated in the roots of perennial ryegrass, and the application of exogenous $\mathrm{NO}$ inhibited $\mathrm{Cd}$ translocation from roots to the shoots (Wang et al., 2013). Therefore, perennial ryegrass can serve as a useful model for studying the physiological basis of $\mathrm{Cd}$ tolerance in perennial grass species. The object of this study was to investigate the mechanism and approaches of SNP for mitigating $\mathrm{Cd}$ stress by determining uptake and translocation of $\mathrm{Cd}$, 
oxidative damages and responses of antioxidative systems in both leaves and roots of ryegrass seedlings. This study focused on the impact of different Cd loadings on the growth of ryegrass seedlings and the alleviating effect of exogenous NO on the damages induced by different $\mathrm{Cd}$ concentrations in ryegrass seedlings.

\section{Materials and Methods}

\subsection{Plant material and culture conditions}

Ryegrass seeds were first sterilized with 5\% sodium hypochlorite for $15 \mathrm{~min}$ and washed extensively with distilled water, then germinated on moist filter paper in the dark at $26^{\circ} \mathrm{C}$ for 3 days. Initially, seedlings of uniform size were transferred to plastic pots (volume $500 \mathrm{~mL}$ ) filled with perlite (50 plants per pot) and watered with half-strength Hoagland nutrition solution for 7 days. The seedlings were then watered with fullstrength Hoagland solution. Three-week-old uniform seedlings were transferred into $1,000 \mathrm{~mL}$ black plastic containers with 50 seedlings per container. The nutrient solution was renewed every 2 days. These treatments contain: CK: Hoagland's solution; SNP: 100 $\mu \mathrm{M}$ SNP-treated nutrient solutions; Cd1: $100 \mu \mathrm{M} \mathrm{Cd}$ treated nutrient solutions; $\mathrm{Cd}$ 2: $150 \mu \mathrm{M}$ Cd-treated nutrient solutions; Cd1+SNP: $100 \mu \mathrm{M}$ SNP added into $100 \mu \mathrm{M}$ Cd-treated nutrient solutions; Cd2 + SNP: $100 \mu \mathrm{M}$ SNP added into $150 \mu \mathrm{M}$ Cd-treated nutrient solutions. Cd was given as $\mathrm{CdCl}_{2}$.

The treatments were arranged in a randomized block design with four replicates. The experiment was carried out under a controlled-environment chamber at 14/10 light/dark photoperiod and photon flux density $150 \mu \mathrm{mol} \mathrm{m}^{-2} \mathrm{~s}^{-1}$ at the leaf level, day/night temperature of $25 / 18^{\circ} \mathrm{C}$ and $65 \pm 5 \%$ relative humidity. After 2 weeks of growth with the above conditions, the plants were harvested and the roots and leaves were sepa- rated and washed with $5 \mathrm{mM} \mathrm{CaCl}_{2}$ (only the roots) first and then repeatedly washed with deionized distilled water. For the estimation of plant dry matter, $\mathrm{Cd}$ and mineral nutrients content, the plants were dried at $80^{\circ} \mathrm{C}$ for $48 \mathrm{~h}$. For the enzyme determination, fresh plant material was frozen in liquid nitrogen and stored at $-70^{\circ} \mathrm{C}$ until use.

\subsection{Determination of plant growth}

Plant height was determined immediately after harvesting. At harvest, the roots and leaves were separated and oven-dried for $30 \mathrm{~min}$ at $105^{\circ} \mathrm{C}$, then at $70^{\circ} \mathrm{C}$ till the materials reach their constant weight. Fresh weight and dry weight were measured.

\subsection{Determination of chlorophyll content}

The chlorophyll content was determined according to the method of Dong et al. (2015). $0.5 \mathrm{~g}$ fresh ryegrass leaf was extracted in $2 \mathrm{~mL} 95 \%$ ethanol for $24 \mathrm{~h}$ in the dark, and the extract was analyzed. The amounts of chlorophyll a, b and carotenoid were determined using a spectrophotometer (SHIMADZU UV-2450, Kyoto, Japan) by reading the absorbance at 665,649 and $470 \mathrm{~nm}$ wavelength. The chlorophyll content is expressed as mg per gram-dry weight ( $\left.\mathrm{mg} \mathrm{g}^{-1} \mathrm{DW}\right)$.

\subsection{Determination of $\mathrm{O}_{2}-$ generation rate}

For the measurement of $\mathrm{O}_{2}^{-{ }^{-}}$generation rate, $0.3 \mathrm{~g}$ fresh leaves were ground in liquid $\mathrm{N}_{2}$ and extracted in $3 \mathrm{~mL}$ of ice cold $50 \mathrm{mM}$ sodium phosphate buffer (PBS) (pH 7.0). One milliliter of the supernatant extract was transferred to a clean test tube and added with $0.9 \mathrm{~mL} 65 \mathrm{mM}$ phosphate buffer solution (pH 7.8) and $0.1 \mathrm{~mL} 10 \mathrm{mM}$ hydroxylammonium chloride. The reaction was incubated at $25{ }^{\circ} \mathrm{C}$ for $35 \mathrm{~min} .0 .5 \mathrm{~mL}$ solution from the above reaction 
mixture was then transferred to another test tube containing $0.5 \mathrm{~mL} 17 \mathrm{mM}$ sulfanic acid and $0.5 \mathrm{~mL}$ $7.8 \mathrm{mM}$ a -naphthylamine solution. After $20 \mathrm{~min}$ of reaction, $2 \mathrm{~mL}$ of ether was added into the above solution, and then mixed well. The solution was centrifuged at $1500 \times \mathrm{g}$ at $4{ }^{\circ} \mathrm{C}$ for $5 \mathrm{~min}$. The absorbance of the pink supernatant was measured at $530 \mathrm{~nm}$ with the spectrophotometer. Absorbance values were calibrated to a standard curve generated with known concentrations of $\mathrm{HNO}_{2}$ (Wang et al. 2013).

\subsection{Determination of $\mathrm{H}_{2} \mathrm{O}_{2}$ concentration}

For determination $\mathrm{H}_{2} \mathrm{O}_{2}$ concentration, leaf tissue $(0.2$ g) was extracted with $3 \mathrm{~mL}$ of $0.1 \%(\mathrm{w} / \mathrm{v})$ trichloroacetic acid (TCA) in an ice bath and centrifuged at $12,000 \times \mathrm{g}$ for $15 \mathrm{~min}$ (Velikova et al. 2000). An aliquot $(0.5 \mathrm{~mL})$ of the extract was transferred to a test tube containing $0.5 \mathrm{~mL}$ of phosphate buffer $(\mathrm{pH} 7.0)$ and $1 \mathrm{ml}$ of $1 \mathrm{M} \mathrm{KI}$. The absorbance of the mixture was read at $390 \mathrm{~nm} . \mathrm{H}_{2} \mathrm{O}_{2}$ content was determined using the extinction coefficient $0.28 \mathrm{M}^{-1} \mathrm{~cm}^{-1}$ and the amount expressed as $\mu \mathrm{mol} \mathrm{g}{ }^{-1} \mathrm{DW}$.

\subsection{Determination of lipid peroxidation and soluble protein}

The level of lipid peroxidation in fresh leaf was measured in terms of malondialdehyde (MDA) concentration by the thiobarbituric acid reaction method (Wang et al., 2016). The MDA concentration was expressed as nmol g-1 DW. Proteins were estimated by the method of $\mathrm{Xu}$ (2014). Fresh leaves $(0.5 \mathrm{~g})$ were homogenized in $1 \mathrm{~mL}$ phosphate buffer $(\mathrm{pH}$ 7.0). The crude homogenate was centrifuged at $5,000 \times \mathrm{g}$ for $10 \mathrm{~min}$. Half $\mathrm{ml}$ of freshly prepared trichloroacetic acid (TCA) was added, mixed well, and then centrifuged at $8,000 \times \mathrm{g}$ for $15 \mathrm{~min}$. After separating from the supernatant solution, the precipitate was dissolved in $1 \mathrm{~mL}$ of $0.1 \mathrm{~N}$ $\mathrm{NaOH}$ and added with $5 \mathrm{~mL}$ Bradford reagent. The absorbance of the final solution was measured at $595 \mathrm{~nm}$ using a spectrophotometer (SHIMADZU UV-2450, Japan).

\subsection{Determination of antioxidant enzyme activities}

For extraction of antioxidative enzymes, leaves and roots were homogenized with $50 \mathrm{mM} \mathrm{Na} \mathrm{HPO}_{4}$ $\mathrm{NaH}_{2} \mathrm{PO}_{4}$ buffer ( $\mathrm{pH}$ 7.8) containing $0.2 \mathrm{mM}$ EDTA and $2 \%$ insoluble polyvinylpyrrolidone in a chilled pestle and mortar. The homogenate was centrifuged at $12,000 \times \mathrm{g}$ for $20 \mathrm{~min}$ and the supernatant was separated and used for determination of enzyme activities. The whole extraction procedure was carried out at $4{ }^{\circ} \mathrm{C}$. All spectrophotometric analysis was conducted on a SHIMADZU UV-2450 spectrophotometer (Kyoto, Japan).

Superoxide dismutase (SOD) activity was assayed by measuring its ability to inhibit the photochemical reduction of nitroblue tetrazolium following the method of Xu et al., (2014). One unit of SOD activity (U) was defined as the amount of crude enzyme extract that is required for inhibiting the reduction rate of nitro-blue tetrazolium by $50 \%$. Guaiacol peroxidase (POD) activity was measured by the increase in absorbance at $470 \mathrm{~nm}$ due to guaiacol oxidation (Wang et al., 2013). Variation of absorbance per minute per milligram protein ( $\triangle \mathrm{A} 470$ min-1mg-1protein) stands for enzymes activity. Catalase (CAT) activity was measured as the decline in absorbance at $240 \mathrm{~nm}$ due to the decrease in the extinction of $\mathrm{H}_{2} \mathrm{O}_{2}$ according to the method of Xu et al. (2014). Unit of CAT activity $\left(\triangle \mathrm{A} 240 \mathrm{~min}^{-1} \mathrm{mg}^{-1}\right.$ protein) was defined as variation of absorbance per minute per milligram protein. 


\subsection{Determination of cadmium and mineral element concentrations}

The dried plant tissues were weighed and ground into powder for the determination of $\mathrm{Cd}$ and other mineral elements using flame atomic absorbance spectrometry (SHIMADZU AA-6300, Kyoto, Japan) after digested with mixed acids $\left[\mathrm{HNO}_{3}+\mathrm{HClO}_{4}\right.$ $(3: 1, \mathrm{v} / \mathrm{v})]$ (Ali et al., 2002).

\subsection{Plasma membrane preparation}

A membrane fraction enriched in plasma membrane vesicles was prepared as described by Wang et al. (2013a) with minor modifications. Excised samples were homogenized $(1 / 2, \mathrm{w} / \mathrm{v})$ with a mortar and pestle in a cold medium containing: $25 \mathrm{mM}$ HEPES-Tris (pH 7.2), $250 \mathrm{mM}$ mannitol, $5 \mathrm{mM}$ EDTA, $1 \mathrm{mM}$ DTT and $1.5 \%(\mathrm{w} / \mathrm{v})$ PVP. The whole isolation procedures were carried out at $4{ }^{\circ} \mathrm{C}$. The homogenate was filtered through four layers of cheesecloth and centrifuged at $560 \times \mathrm{g}$ for $12 \mathrm{~min}$, then the supernatant was centrifuged at $10,000 \times \mathrm{g}$ for $15 \mathrm{~min}$, and after separating from the precipitate, the supernatant was centrifuged at $60,000 \times \mathrm{g}$ for $30 \mathrm{~min}$ to yield a crude membrane fraction. The resulted pellet was resuspended with $1 \mathrm{~mL}$ in a gradient buffer containing: 20 mM HEPES-Tris (pH 7.5), 5 mM EDTA, and $0.5 \mathrm{mM}$ EGTA. The supernatant was layered on top of a step gradient consisting of $1 \mathrm{~mL}$ of $45 \%, 33 \%$, and $15 \%$ $(\mathrm{w} / \mathrm{w})$ sucrose, respectively, and then centrifuged for $2 \mathrm{~h}$ at $70,000 \times \mathrm{g}$ force.

2.10. Measurement of $H^{+}$-ATPase in plasma membrane (PM) vesicles

ATP hydrolysis assays were performed on plasma membrane (PM) vesicles as described by Wang et al. (2013). $0.5 \mathrm{~mL}$ of the reaction medium contain-

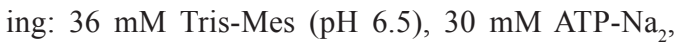
$3 \mathrm{mM} \mathrm{MgSO}_{4}, 1 \mathrm{mM} \mathrm{NaN}_{3}, 50 \mathrm{mM} \mathrm{KNO}_{3}, 1 \mathrm{mM}$ $\mathrm{Na}_{2} \mathrm{MoO}_{4}, 0.02 \%$ (v/v) Triton X-100 was used in the presence or absence of $2.5 \mathrm{mM} \mathrm{Na} \mathrm{VO}_{4}$. The reaction was triggered by adding $50 \mu \mathrm{L}$ PM vesicles. After $30 \mathrm{~min}$ incubation at $37^{\circ} \mathrm{C}$, the reaction was quenched by the addition of $55 \%(\mathrm{w} / \mathrm{v}) \mathrm{TCA}$. The $\mathrm{H}^{+}$-ATPase activity was determined by measuring the release of Pi (Dong et al., 2015).

\subsection{Statistical analysis}

The experiment was a completely random design with three replications. Statistical analyses were carried out by analysis of variance (ANOVA) using SAS software (SAS Institute, Cary NC). Differences between treatments were separated by the least significant difference (LSD) test at a 0.05 probability level.

\section{Results}

\subsection{Plant growth}

After $14 \mathrm{~d}$ of Cd exposure, ryegrass seedlings showed severe morphological disturbances, including stunted growth, brownish roots, chlorosis and necrosis on the leaves, especially under $150 \mu \mathrm{M} \mathrm{Cd}$ stress (Table 1). SNP treatment alone did not affect seedlings growth, as compared to $\mathrm{CK}$. Cd exposure significantly decreased the growth of ryegrass seedlings. However, addition of $100 \mu \mathrm{M}$ SNP substantially alleviated Cd toxicity of plants especially under the $150 \mu \mathrm{M} \mathrm{Cd}$ stress. For example, exogenous NO increased shoot height by $14.81 \%$ under $100 \mu \mathrm{M} \mathrm{Cd}$ stress and by $16.26 \%$ under $150 \mu \mathrm{M} C d$ stress. Similar trends were noted in the root length, fresh weight, dry weight, and root/shoot ratio and root volume. 
Table 1. Effects of SNP on biomass yield of ryegrass plants after 14 days treatment of Cd stress .

\begin{tabular}{lllllll}
\hline Treatments & $\begin{array}{l}\text { Shoot height } \\
(\mathrm{cm} / \text { plant })\end{array}$ & $\begin{array}{l}\text { Root length } \\
(\mathrm{cm} / \text { plant })\end{array}$ & $\begin{array}{l}\text { Fresh weight } \\
(\mathrm{g} / 50 \text { plant })\end{array}$ & $\begin{array}{l}\text { Dry weight } \\
(\mathrm{g} / 50 \text { plant })\end{array}$ & $\begin{array}{l}\text { Root/shoot } \\
\text { ratio }\end{array}$ & $\begin{array}{l}\text { root volume } \\
(\mathrm{mL} / 50 \\
\text { plant })\end{array}$ \\
\hline $\mathrm{CK}$ & $31.09 \pm 0.50 \mathrm{a}$ & $16.20 \pm 0.24 \mathrm{a}$ & $9.61 \pm 0.53 \mathrm{a}$ & $1.37 \pm 0.07 \mathrm{a}$ & $0.14 \pm 0.01 \mathrm{a}$ & $3.88 \pm 0.04 \mathrm{a}$ \\
$\mathrm{SNP}$ & $30.41 \pm 0.59 \mathrm{a}$ & $15.58 \pm 1.10 \mathrm{a}$ & $9.21 \pm 0.74 \mathrm{a}$ & $1.30 \pm 0.06 \mathrm{a}$ & $0.15 \pm 0.01 \mathrm{ab}$ & $3.82 \pm 0.08 \mathrm{a}$ \\
$\mathrm{Cd} 1$ & $25.26 \pm 0.53 \mathrm{~d}$ & $7.93 \pm 0.09 \mathrm{c}$ & $6.87 \pm 0.17 \mathrm{c}$ & $0.98 \pm 0.02 \mathrm{c}$ & $0.11 \pm 0.01 \mathrm{c}$ & $2.52 \pm 0.04 \mathrm{~d}$ \\
$\mathrm{Cd} 2$ & $23.01 \pm 0.19 \mathrm{e}$ & $7.00 \pm 0.42 \mathrm{~d}$ & $5.78 \pm 0.25 \mathrm{~d}$ & $0.86 \pm 0.02 \mathrm{~d}$ & $0.10 \pm 0.00 \mathrm{~d}$ & $2.27 \pm 0.03 \mathrm{e}$ \\
$\mathrm{Cd} 1+\mathrm{SNP}$ & $29.00 \pm 0.71 \mathrm{~b}$ & $9.73 \pm 0.33 \mathrm{~b}$ & $8.43 \pm 0.22 \mathrm{~b}$ & $1.20 \pm 0.02 \mathrm{~b}$ & $0.13 \pm 0.00 \mathrm{~b}$ & $3.37 \pm 0.04 \mathrm{~b}$ \\
$\mathrm{Cd} 2+\mathrm{SNP}$ & $26.75 \pm 0.27 \mathrm{c}$ & $8.99 \pm 0.21 \mathrm{~b}$ & $8.13 \pm 0.22 \mathrm{~b}$ & $1.15 \pm 0.07 \mathrm{c}$ & $0.11 \pm 0.00 \mathrm{c}$ & $3.22 \pm 0.04 \mathrm{c}$ \\
\hline
\end{tabular}

Values are the mean of four replicates. Each replicate has 50 plants. Means followed by different letters within the same column are significantly different at $P<0.05$

\subsection{Chlorophyll content}

Ryegrass plants treated with both 100 and $150 \mu \mathrm{M}$ Cd showed a significant decrease in total chlorophyll, chl a, chl b, chl a $+\mathrm{b}$, and car content as compared to the control (Table 2). However, these inhibitions were alleviated by addition of SNP. Cd1+SNP treatment increased total chlorophyll, chl a, chl b and car content by 17.92, 16.29, 27.78, and $28.56 \%$, respectively. And the corresponding values for Cd2 + SNP treatment were 30.75, 27.00, 38.14 and $59.63 \%$.

Table 2. Effects of SNP on the chlorophyll contents of ryegrass plants after 14 days treatment of Cd stress.

\begin{tabular}{lllllll}
\hline Treatments & $\begin{array}{l}\text { Shoot height } \\
\text { (cm/plant) }\end{array}$ & $\begin{array}{l}\text { Root length } \\
\text { (cm/plant) }\end{array}$ & $\begin{array}{l}\text { Fresh weight } \\
(\mathrm{g} / 50 \text { plant })\end{array}$ & $\begin{array}{l}\text { Dry weight } \\
(\mathrm{g} / 50 \text { plant })\end{array}$ & $\begin{array}{l}\text { Root/shoot } \\
\text { ratio }\end{array}$ & $\begin{array}{l}\text { root volume } \\
(\mathrm{mL} / 50 \\
\text { plant })\end{array}$ \\
\hline $\mathrm{CK}$ & $31.09 \pm 0.50 \mathrm{a}$ & $16.20 \pm 0.24 \mathrm{a}$ & $9.61 \pm 0.53 \mathrm{a}$ & $1.37 \pm 0.07 \mathrm{a}$ & $0.14 \pm 0.01 \mathrm{a}$ & $3.88 \pm 0.04 \mathrm{a}$ \\
$\mathrm{SNP}$ & $30.41 \pm 0.59 \mathrm{a}$ & $15.58 \pm 1.10 \mathrm{a}$ & $9.21 \pm 0.74 \mathrm{a}$ & $1.30 \pm 0.06 \mathrm{a}$ & $0.15 \pm 0.01 \mathrm{ab}$ & $3.82 \pm 0.08 \mathrm{a}$ \\
$\mathrm{Cd} 1$ & $25.26 \pm 0.53 \mathrm{~d}$ & $7.93 \pm 0.09 \mathrm{c}$ & $6.87 \pm 0.17 \mathrm{c}$ & $0.98 \pm 0.02 \mathrm{c}$ & $0.11 \pm 0.01 \mathrm{c}$ & $2.52 \pm 0.04 \mathrm{~d}$ \\
$\mathrm{Cd} 2$ & $23.01 \pm 0.19 \mathrm{e}$ & $7.00 \pm 0.42 \mathrm{~d}$ & $5.78 \pm 0.25 \mathrm{~d}$ & $0.86 \pm 0.02 \mathrm{~d}$ & $0.10 \pm 0.00 \mathrm{~d}$ & $2.27 \pm 0.03 \mathrm{e}$ \\
$\mathrm{Cd} 1+\mathrm{SNP}$ & $29.00 \pm 0.71 \mathrm{~b}$ & $9.73 \pm 0.33 \mathrm{~b}$ & $8.43 \pm 0.22 \mathrm{~b}$ & $1.20 \pm 0.02 \mathrm{~b}$ & $0.13 \pm 0.00 \mathrm{~b}$ & $3.37 \pm 0.04 \mathrm{~b}$ \\
$\mathrm{Cd} 2+\mathrm{SNP}$ & $26.75 \pm 0.27 \mathrm{c}$ & $8.99 \pm 0.21 \mathrm{~b}$ & $8.13 \pm 0.22 \mathrm{~b}$ & $1.15 \pm 0.07 \mathrm{c}$ & $0.11 \pm 0.00 \mathrm{c}$ & $3.22 \pm 0.04 \mathrm{c}$ \\
\hline
\end{tabular}

Values are the mean of four replicates. Each replicate has 50 plants. Means followed by different letters within the same column are significantly different at $P<0.05$

\section{3. $\mathrm{O}_{2}$ generation rate and hydrogen peroxide concentration}

$\mathrm{O}_{2} \cdot$ generation rate and $\mathrm{H}_{2} \mathrm{O}_{2}$ concentration showed significant rises in leaves and roots under both 100 and $150 \mu \mathrm{M}$ Cd stress, as compared to the control (Figure 1). $\mathrm{O}_{2}{ }^{-}$generation rate and $\mathrm{H}_{2} \mathrm{O}_{2}$ concentration in leaves and roots were not affected by SNP application alone. Seedlings subjected to $150 \mu \mathrm{M} \mathrm{Cd}$ exhibited substantial $\mathrm{O}_{2}$ generation rate acceleration in leaves and roots, which were increased by $76.76 \%$ and $285 \%$. Addition of SNP significantly decreased the $\mathrm{O}_{2}$ generation rate and $\mathrm{H}_{2} \mathrm{O}_{2}$ concentration in leaves and roots of plants under $\mathrm{Cd}$ stress, particularly $150 \mu \mathrm{M} \mathrm{Cd}$ exposure. 
(b)
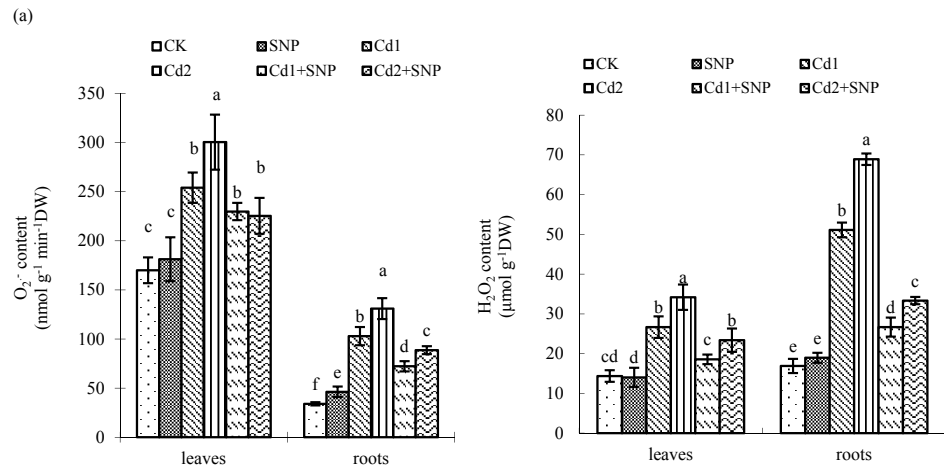

Figure 1. Effects of SNP on $\mathrm{O}_{2}^{--}$generation rate (a) and $\mathrm{H}_{2} \mathrm{O}_{2}$ content (b) in leaves and roots of ryegrass plants after 14 days treatment of $\mathrm{Cd}$ stress. Values are the mean of four replicates. Each replicate has 50 plants. Bars with different letters are significantly different at $P<0.05$.

\subsection{MDA and soluble protein contents}

When plants were subjected to environmental stress, oxidative damage resulted in membrane lipid peroxidation, which could be estimated by MDA levels. Figure 2a showed that both 100 and $150 \mu \mathrm{M} \mathrm{Cd}$ exposure increased MDA concentration in plants significantly. However, addition of SNP to the 100 and $150 \mu \mathrm{M} \mathrm{Cd}$ treatments decreased MDA concentration by 18.60
$\%, 20.41 \%$ in leaves and $24.72 \%, 22.57 \%$ in roots, respectively.

Ryegrass seedlings treated with $\mathrm{Cd}$ (100 and 150 $\mu \mathrm{M}$ ) showed significant declines in soluble protein content in both leaves and roots (Figure 2b). However, this decline was alleviated by the addition of SNP. SNP treatment increased soluble protein content by $95.1 \%$ in leaves and $58.19 \%$ in roots, as compared to $\mathrm{Cd} 2$ treatment.
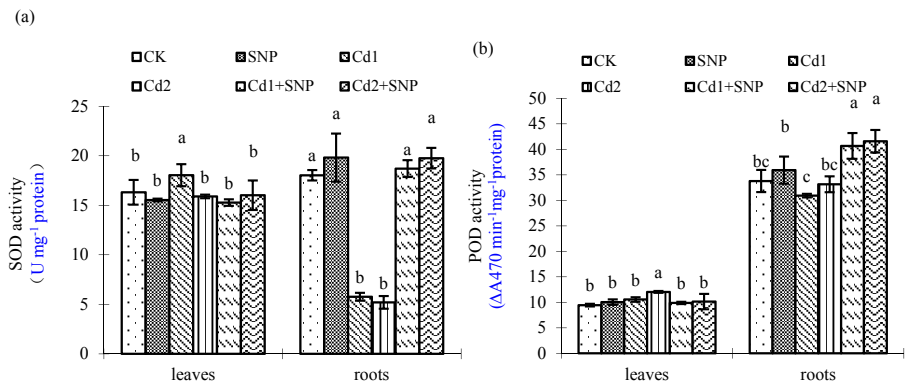

Figure 2. Effects of SNP on MDA (a) and soluble protein content (b) in leaves and roots of ryegrass plants after 14 days treatment of $\mathrm{Cd}$ stress.. Values are the mean of four replicates. Each replicate has 50 plants. Bars with different letters are significantly different at $P<0.05$. 


\subsection{Antioxidant enzymes activities}

The effects of Cd and SNP on activities of antioxidant enzymes were presented in Figure 3. Cd treatments (100 and $150 \mu \mathrm{M} \mathrm{Cd})$ increased the activities of SOD, POD and CAT in leaves, but reduced them in roots. Addition of SNP alleviated $\mathrm{Cd}$ stresses by increasing the activities of SOD, POD and CAT in leaves and restored them in roots.

(a)
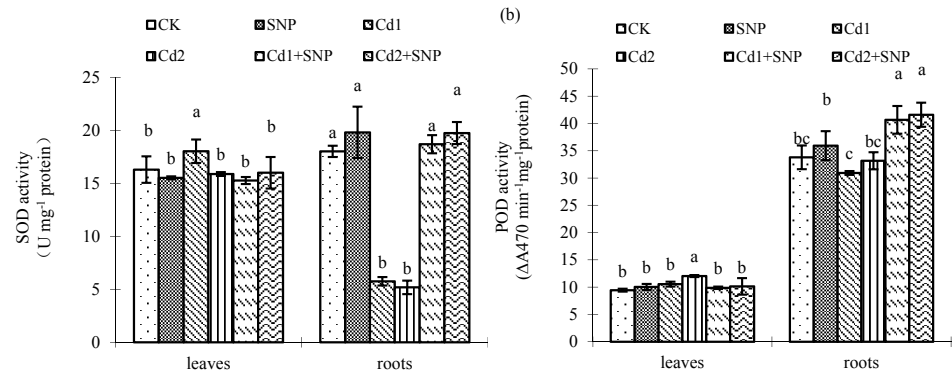

(c)

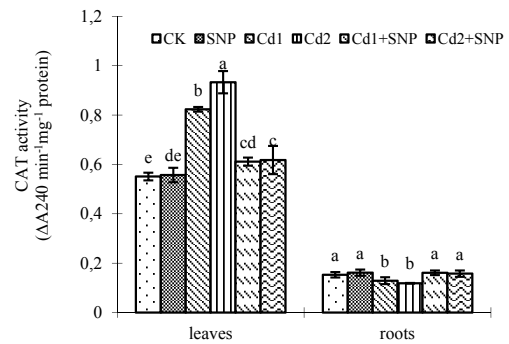

Figure 3. Effects of SNP on SOD (a), CAT (b) and POD (c) content in leaves and roots of ryegrass plants after 14 days treatment of $\mathrm{Cd}$ stress. Values are the mean of four replicates. Each replicate has 50 plants. Bars with different letters are significantly different at $P<0.05$.

\section{6. $\mathrm{Ca}, \mathrm{Fe}, \mathrm{Cu}, \mathrm{Zn}$ and $\mathrm{Mg}$ concentrations}

$\mathrm{Cd} 1$ and $\mathrm{Cd} 2$ treatments significantly decreased $\mathrm{Fe}$, $\mathrm{Cu}$ and $\mathrm{Zn}$ concentration in both leaves and roots, but $\mathrm{Ca}$ concentration was increased in leaves while decreased in root. (Table 3). In contrast with $\mathrm{Ca}, \mathrm{Mg}$ concentration was decreased in leaves but increased in roots. The reduction of $\mathrm{Fe}, \mathrm{Cu}$ and $\mathrm{Zn}$ concentration was more obvious at the higher $\mathrm{Cd}$ treatment level $(150 \mu \mathrm{M})$. Addition of SNP alleviated Cd stress by raising $\mathrm{Fe}, \mathrm{Cu}$ and $\mathrm{Zn}$ concentration in plant. For instance, $\mathrm{Cd} 2+\mathrm{SNP}$ treatment increased $\mathrm{Fe}, \mathrm{Cu}$ and Zn concentrations by $39.77 \%, 29.56 \%$ and $39.61 \%$, respectively in leaves and by $76.71 \%, 51.89 \%$ and $26.86 \%$, respectively in roots, as compared to $\mathrm{Cd} 2$ treatment alone. Moreover, SNP addition increased $\mathrm{Mg}$ concentration in leaves and $\mathrm{Ca}$ concentration in roots, particularly under $150 \mu \mathrm{M}$ Cd stress. 
Table 3. Effects of SNP on the mineral contents $\left(\mathrm{mg} \mathrm{kg}^{-1} \mathrm{DW}\right)$ in shoots and roots of ryegrass plants after 14 days treatment of Cd stress.

\begin{tabular}{|c|c|c|c|c|c|c|c|}
\hline \multirow{2}{*}{\multicolumn{2}{|c|}{ Items }} & \multicolumn{6}{|c|}{ Treatments } \\
\hline & & $\mathrm{CK}$ & SNP & $\mathrm{Cd} 1$ & $\mathrm{Cd} 2$ & $\mathrm{Cd} 1+\mathrm{SNP}$ & $\mathrm{Cd} 2+\mathrm{SNP}$ \\
\hline \multirow{3}{*}{$\mathrm{Ca}$} & shoots & $327.9 \pm 10.48 \mathrm{~d}$ & $399.30 \pm 5.77 \mathrm{~b}$ & $426.16 \pm 4.58 \mathrm{a}$ & $416.14 \pm 9.59 \mathrm{a}$ & $366.55 \pm 13.29 \mathrm{c}$ & $336.16 \pm 2.83 \mathrm{~d}$ \\
\hline & roots & $143.6 \pm 10.60 \mathrm{a}$ & $110.13 \pm 3.03 \mathrm{~cd}$ & $118.22 \pm 5.92 \mathrm{c}$ & $106.73 \pm 0.78 \mathrm{~d}$ & $132.36 \pm 3.41 \mathrm{~b}$ & $134.11 \pm 4.20 \mathrm{ab}$ \\
\hline & shoots & $360.4 \pm 17.40 \mathrm{a}$ & $338.20 \pm 7.99 \mathrm{a}$ & $241.34 \pm 13.77 \mathrm{~d}$ & $195.09 \pm 22.45 \mathrm{e}$ & $306.83 \pm 3.45 \mathrm{~b}$ & $272.68 \pm 9.59 \mathrm{c}$ \\
\hline $\mathrm{Fe}$ & roots & $4949 \pm 40.41 \mathrm{a}$ & $\begin{array}{l}3669.13 \pm 43.87 \\
\text { d }\end{array}$ & $\begin{array}{l}2938.72 \pm 33.70 \\
\mathrm{e}\end{array}$ & $\begin{array}{l}2399.95 \pm 92.17 \\
\text { f }\end{array}$ & $\begin{array}{l}4512.41 \pm 74.11 \\
b\end{array}$ & $\begin{array}{l}4241.05 \pm 40.17 \\
\mathrm{c}\end{array}$ \\
\hline \multirow{2}{*}{$\mathrm{Cu}$} & shoots & $8.46 \pm 0.05 \mathrm{a}$ & $7.06 \pm 0.10 \mathrm{c}$ & $6.00 \pm 0.15 \mathrm{~d}$ & $5.48 \pm 0.09 \mathrm{e}$ & $7.54 \pm 0.04 \mathrm{~b}$ & $7.09 \pm 0.06 \mathrm{c}$ \\
\hline & roots & $44.93 \pm 0.67 \mathrm{a}$ & $37.85 \pm 0.33 \mathrm{~b}$ & $31.23 \pm 0.35 \mathrm{~d}$ & $23.76 \pm 0.62 \mathrm{e}$ & $38.45 \pm 1.45 \mathrm{~b}$ & $36.09 \pm 1.28 \mathrm{c}$ \\
\hline \multirow{2}{*}{$\mathrm{Zn}$} & shoots & $811.5 \pm 7.22 \mathrm{a}$ & $571.01 \pm 10.64 \mathrm{~d}$ & $495.10 \pm 1.45 \mathrm{e}$ & $462.75 \pm 4.89 \mathrm{f}$ & $691.35 \pm 5.66 \mathrm{~b}$ & $646.06 \pm 8.28 \mathrm{c}$ \\
\hline & roots & $1038 \pm 29.69 \mathrm{a}$ & $887.18 \pm 8.49 \mathrm{c}$ & $830.94 \pm 3.37 \mathrm{~d}$ & $747.00 \pm 18.85 \mathrm{e}$ & $975.54 \pm 12.10 \mathrm{~b}$ & $947.61 \pm 7.02 \mathrm{~b}$ \\
\hline \multirow{2}{*}{$\mathrm{Mg}$} & shoots & $1755 \pm 6.68 \mathrm{a}$ & $1711.79 \pm 7.93 \mathrm{~b}$ & $1591.71 \pm 3.47 \mathrm{e}$ & $1502.00 \pm 6.66 \mathrm{f}$ & $1650.46 \pm 4.23 \mathrm{c}$ & $1629.34 \pm 6.09 \mathrm{~d}$ \\
\hline & roots & $2202 \pm 2.37 \mathrm{~d}$ & $2206.23 \pm 2.78 \mathrm{~d}$ & $2678.19 \pm 2.24 \mathrm{c}$ & $3273.79 \pm 2.92 \mathrm{a}$ & $2154.31 \pm 3.39 \mathrm{e}$ & $2753.93 \pm 6.15 \mathrm{~b}$ \\
\hline
\end{tabular}

Values are the mean of four replicates. Each replicate has 50 plants. Means followed by different letters within the same column are significantly different at $P<0.05$.

\subsection{Cd concentration in leaves and roots}

Cd concentrations were significantly higher in roots than in leaves at both the $\mathrm{Cd} 1$ and $\mathrm{Cd} 2$ treatments (Figure 4), although Cd concentration in both leaves and roots was elevated with increasing $\mathrm{Cd}$ concentration in nutrient solution.
Addition of SNP decreased Cd concentration in leaves but increased it in roots, especially at the $\mathrm{Cd} 2$ treatment. Addition of SNP to the 100 and $150 \mu \mathrm{M}$ Cd solutions decreased Cd concentration by $21.04 \%$ and $21.55 \%$, respectively in leaves, but increased by $24.80 \%$ and $38.06 \%$ respectively, in roots.

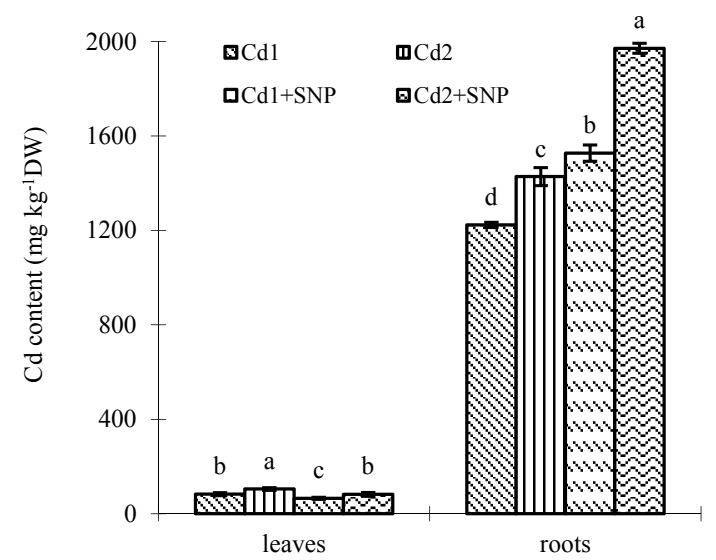

Figure 4. Effects of SNP on Cd content in leaves and roots of ryegrass plants after 14 days treatment of Cd stress. The values of control and SNP treatments were $0 \mathrm{mg} \mathrm{kg}^{-1} \mathrm{DW}$. Values are the mean of four replicates. Each replicate has 50 plants. Bars with different letters are significantly different at $P<0.05$. 


\section{8. $H^{+}$-ATPase activity in plasma membrane}

As shown in Figure 5, Cd stresses decreased $\mathrm{H}^{+}$ATPase activity in leaves and roots, especially at the $150 \mu \mathrm{M} \mathrm{Cd}$. In plants with $\mathrm{Cd} 1$ and $\mathrm{Cd} 2$ treatments, $\mathrm{H}^{+}$-ATPase activity was decreased by
$56.89 \%$ and $67.08 \%$, respectively in leaves and by $52.37 \%$ and $62.38 \%$, respectively in roots, as compared to CK. However, exogenous NO application restored $\mathrm{H}^{+}$-ATPase activity in both leaves and roots, especially with the $\mathrm{Cd} 2+$ SNP treatment.

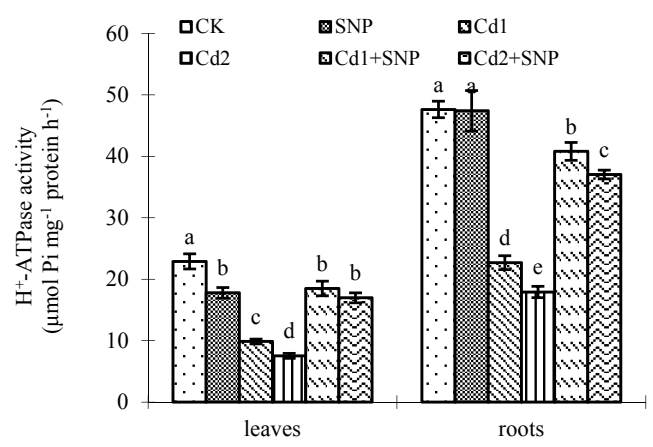

Figure 5. Effects of SNP on $\mathrm{H}^{+}$-ATPase activity in leaves and roots of ryegrass plants after 14 days treatment of Cd stress. Values are the mean of four replicates. Each replicate has 50 plants. Bars with different letters are significantly different at $P<0.05$.

\section{Discussion}

The mechanisms of $\mathrm{NO}$ as a signaling regulatory molecule and reactive oxygen scavenger in improving plant tolerance to $\mathrm{Cd}$ stress were poorly understood. In the present study, the growth of ryegrass plants was significantly affected by $\mathrm{Cd}$ stress, including reduced plant height, root length, fresh weight, dry weight, root/shoot ratio and root volume (Table 1). Kovaik et al. (2014a) also noted that Mn excess depressed plant growth (but not germination). The inhibition of growth in ryegrass might be resulted from the alteration of fundamental metabolic processes, chlorophyll content (Table 2), antioxidative system (Figure 3) and uptake of mineral elements (Table 3) in leaves and roots under $\mathrm{Cd}$ stress. However, the inhibitory effects were significantly alleviated by exogenous $\mathrm{NO}$, and the mitigation effect of $\mathrm{NO}$ on ryegrass under 150 $\mu \mathrm{M}$ Cd stress was greater than $100 \mu \mathrm{M} \mathrm{Cd}$ stress. The stimulation of plant growth by NO has also been reported in ryegrass (Wang et al., 2013), barley (Chen et $a l ., 2010$ ) and peanut (Xu et al., 2014). The alleviation of Cd stress by NO may be related to increased chlorophyll content (Table 2), improved nutrient balance (Table 3), better regulated activities of antioxidant enzymes (Figure 3), and inhibited Cd translocation from roots to the leaves (Figure 4), thus enhancing the tolerance of ryegrass plants to $\mathrm{Cd}$ toxicity.

A notable reduction of chlorophyll parameters occurred in ryegrass seedlings exposed to $100 \mu \mathrm{M}$ and $150 \mu \mathrm{M} \mathrm{Cd}$ stress (Table 2). Several authors reported a decreased chlorophyll content in the leaves of Cdtreated plants (Belkhadi et al., 2010). The decrease in chlorophyll content in Cd-affected ryegrass seedlings might be attributed to the possible oxidation of chlorophyll and the damaged ultrastructure of chloroplasts 
(Chen et al., 2010). In addition, the decline in chlorophyll content may be due to the decreased $\mathrm{Mg}$ content in leaves under Cd stress (Table 3), which is an essential element in the synthesis of chlorophyll. However, these effects were reverted by NO, suggesting its protecting role against $\mathrm{Cd}$ induced toxicity which is corroborated with previous reports (Ekmekçi et al., 2008). Our previous study also noted that increased uptake of $\mathrm{Fe}$ and $\mathrm{Mg}$ by $\mathrm{NO}$ application was responsible for improving chlorophyll synthesis (Wang et al., 2013). Furthermore, treatment with Cd plus SNP induced a substantial increase of PCs, which might protect photosynthesis (Xiong et al., 2009). In addition, NO effectively reduced the level of ROS generation during Cd stress, and thus resulted in alleviation of the oxidative negative effects of ROS on growth and chlorophyll content, thus improving the tolerance of ryegrass seedlings to Cd stress.

To maintain metabolic functions under stress conditions, the balance between generation and degradation of ROS is essential, otherwise oxidative injuries may occur. In this study, we observed that the treatment of $100 \mu \mathrm{M}$ and $150 \mu \mathrm{M} \mathrm{Cd}$ enhanced the accumulation of $\mathrm{O}_{2}^{--}, \mathrm{H}_{2} \mathrm{O}_{2}$ (Figure 1) and MDA (Figure 2a), especially with the $150 \mu \mathrm{M} \mathrm{Cd}$. The increased ROS production may trigger lipid peroxidation, DNA damage and oxidative modifications of proteins, which can eventually lead to cellular dysfunction and necrotic cell death. The growth inhibition might be partly due to enhanced production and accumulation of ROS. The level of ROS in plant tissues is controlled by an antioxidant system that consists of antioxidant enzymes (SOD, POD, CAT and glutathione reductase) (Schutzendubel and Polle, 2002) and nonenzymatic low molecular weight antioxidants (glutathione and ascorbic acid etc.). Therefore, it was expected that the exposure of ryegrass seedlings to $\mathrm{Cd}$ could elevate the level of antioxidant enzymes. So, the interesting thing that emerged in the present study was that the treatment of plants with $\mathrm{Cd}$ increased the activities of SOD, POD and CAT at a degree in shoots while inhibited these enzymes in roots (Figure 3). Kovacik et al. (2015) also indicated that antioxidative enzyme activities showed significantly higher values in $10 \mu \mathrm{M}$ treatments of both $\mathrm{Cr}$ oxidation states. This may be due to the fact that plants have evolved a complex antioxidant system to avoid the harmful effects of ROS. However, exogenous NO prevented Cd-induced increase in the activities of antioxidant enzymes (SOD, POD and CAT) in leaves but enhanced these activities of antioxidant enzymes in roots. The regulation in the activities of antioxidant enzymes by SNP alleviated the stress of ryegrass and scavenged the $\mathrm{O}_{2}{ }^{-}$and $\mathrm{H}_{2} \mathrm{O}_{2}$ (Figure 1), as well as MDA (Figure 2a). So the stimulation of antioxidant production may suggest that NO can stabilize the cell membranes, counteract oxidative damages and protect ryegrass against stressful condition. Soluble protein content in organisms is an important indicator of reversible and irreversible changes in metabolism and responds to a wide variety of stressors (Singh and Tewari, 2003). In the present study, the soluble protein content in leaves and roots declined under Cd stress, especially at $150 \mu \mathrm{M} \mathrm{Cd}$ (Figure 2b). Our studies coincide with Wang et al. (2013) who reported that $\mathrm{Cd}$ stress caused a decrease in soluble protein content in isolated mitochondria. Generation of $\mathrm{H}_{2} \mathrm{O}_{2}$, and other ROS may directly correlate with damage to proteins. Moreover, Cd forms disulfide bridges within proteins leading to distorted membrane ion channels and leakage of ions (Verma et al., 2013). Interestingly, NO-treatment caused a marked enhancement of $\mathrm{Cd}$-induced soluble protein content in leaves and roots, which indicated that the seedlings were partially relieved from $\mathrm{Cd}$ stress. And the relief effect of NO was greater under $150 \mu \mathrm{M}$ $\mathrm{Cd}$ than $100 \mu \mathrm{M}$ Cd stress. 
Metal excess typically depresses accumulation of mineral nutrients in plants (Kovacik et al., 2014a). Our study indicated a marked change in mineral nutrient concentration occurred in ryegrass leaves and roots under Cd stress, and this effect was almost completely regulated when plants were treated with NO (Table 3). Previous studies have reported excess of $\mathrm{Cd}$ usually affects accumulation of essential mineral nutrients (Kovacik et al., 2009), which may account for the reduction of $\mathrm{Fe}$, $\mathrm{Mg}, \mathrm{Cu}$, and $\mathrm{Zn}$ concentration in leaves and $\mathrm{Fe}$, $\mathrm{Ca}, \mathrm{Cu}$, and $\mathrm{Zn}$ concentration in roots (Table 3). On the contrary to these elements, Ca concentrations in leaves were increased under $\mathrm{Cd}$ toxicity, which may be due to the fact that cell wall is the main store for $\mathrm{Ca}$ in plant and the accumulation of $\mathrm{Ca}$ may facilitate to reduce the detrimental effect of $\mathrm{Cd}$. Changes of mineral concentration indicated that $\mathrm{Cd}$ disturbed ionic homeostasis and NO stimulated its maintenance, especially under the $150 \mu \mathrm{M}$ Cd stress. In addition, $\mathrm{H}^{+}$-ATPase in plasma membrane plays an important role in the transport of multiple ions (Wang et al., 2016), and this study indicated that $\mathrm{NO}$ treatment induced the absorption of plasma membrane $\mathrm{H}^{+}$-ATPase activity under $\mathrm{Cd}$ toxicity (Figure 5), which might be responsible for $\mathrm{NO}$ to adjust ion balance by increasing $\mathrm{Fe}, \mathrm{Cu}$, and $\mathrm{Zn}$ concentrations (Table 3 ). Moreover, an increase in $\mathrm{H}^{+}$-ATPase activity is the mechanism of protecting the integrity of plasma membrane, which can improve the resistance to $\mathrm{Cd}$ toxicity. So the plants can absorb more mineral nutrients and maintain ionic homeostasis.

In plants, the root is in direct contact with $\mathrm{Cd}$ and the cell walls of roots play a significant role in heavy metal tolerance (Xiong et al. 2009). In the present study, Cd concentrations in different plant tissues of ryegrass decreased in the order of roots $>$ leaves (Figure 4), which implies that the translocation of
$\mathrm{Cd}$ from roots to the shoots is restricted by internal barriers to defend the shoots. In addition, treatment with $150 \mu \mathrm{M} \mathrm{Cd}$ induced a more obvious increase of $\mathrm{Cd}$ concentrations in both leaves and roots. This result is similar to that reported for wheat (Singh et al., 2008). However, NO elevated Cd uptake in plants while inhibited the root-to-shoot translocation of $\mathrm{Cd}$ (Figure 4), thus resulting in lower $\mathrm{Cd}$ accumulation in leaves, this may be an important mechanism for NO-increased $\mathrm{Cd}$ tolerance. Our data agree with those reported in chamomile where SNP enhanced Cd uptake (Kovacik et al., 2014b). Therefore, this may be an important tolerance mechanism of metal exclusion. Concurred to our findings, exogenous $\mathrm{NO}$ reduced the root-to-shoot translocation of $\mathrm{Cd}$ in ryegrass plants under $\mathrm{Cd}$ stress (Wang et al., 2013). This may be due to the fact that the exogenous $\mathrm{NO}$ increased $\mathrm{Fe}, \mathrm{Mg}, \mathrm{Cu}$, and $\mathrm{Zn}$ concentrations in leaves, and thus reduce $\mathrm{Cd}$ accumulation in seedlings. Moreover, previous reports also indicated that SNP induced an increase in $\mathrm{Cd}$ accumulation in the cell wall of roots, which may in turn decreased $\mathrm{Cd}$ translocation from roots into the leaves (Xiong et al., 2009).

\section{Conclusion}

The present study demonstrated that exogenous NO could alleviate $\mathrm{Cd}$ toxicity to ryegrass plants and the ameliorated effect was more evident under the high $\mathrm{Cd}$ stress. The relief mechanisms of exogenous $\mathrm{NO}$ in alleviating $\mathrm{Cd}$ toxicity in ryegrass may be related to: (1) increased chlorophyll concentration; (2) reduced oxidative stress and improved antioxidative system; (3) regulated mineral nutrient balance in leaves and roots; and (4) decreased $\mathrm{Cd}$ translocation from roots to the leaves. These results may be applicable to other plant species under different heavy metal stress. 


\section{Acknowledgements}

This work was financially supported by the Shandong Provincial Natural Science Foundation of China (ZR2017MD010), and the Primary Research \& Development Plan of Shandong Province (2016CYJS05A02 ). The authors also thank Dr. Zhenli He (Soil and Water Science Department, Florida University, USA), for his critical reading and revision of the manuscript.

\section{Reference}

Ali, N.A., Bernal, M.P., Ater, M. 2002. Tolerance and bioaccumulation of copper in Phragmites australis and Zea mays. Plant Soil. 239:103-111.

Arienzo, M., Adamo, P., Cozzolino, V. 2004. The potential of Lolium perenne for revegetation of contaminated soil from a metallur-gical site. Sci Total Environ. 319:13-25.

Belkhadi, A., Hediji, H., Abbes, Z., Nouairi, I., Barhoumi, Z., Zarrouk, M., Chabi, W., Djebali, W. 2010. Effects of exogenous salicylic acid pretreatment on cadmium toxicity and leaf lipid content in Linum usitatissimum L. Ecotoxicol Environ Saf .73:1004-1011.

Chen, F., Wang, F., Sun, H.Y., Cai, Y., Miao, W.H., Zhang, G.P., Vincze, E., Wu, F.B. 2010. Genotype-dependent effect of exogenous nitric oxide on Cd-induced changes in antioxidative metabolism, ultrastructure, and photosynthetic performance in barley seedlings (Hordeum vulgare). J Plant Growth Regul. 29:394-408.

Chen, G., Liu, Y.Q., Wang, R.M., Zhang, J.F., Owens, G. 2013. Cadmium adsorption by willow root: the role of cell walls and their subfractions. Environ Sci Pollut Res. 20:5665-5672.

De, D.N. 2000. Plant Cell Vacuoles. CSIRO Publishing, Collingwood, Australia.
Dong ,Y.J., Wang, Z.L. , Zhang, J.W. , Liu, S., He, Z.L. , He, M.R. 2015. Interaction effects of nitric oxideand salicylic acid in alleviating salt stress of Gossypium hirsutum L.Journal of Soil Science and Plant Nutrition. 15 (3), 561-573.

Ekmekçi, Y., Tanyolaç, D., Ayhan, B.2008. Effects of cadmium on antioxidant enzyme and photosynthetic activities in leaves of two maize cultivars. Journal of Plant Physiology. 165:600-611.

Gallego, S.M., Pena, L.B., Barcia, R.A., Azpilicueta, C.E., Iannone, M.F., Rosales, E.P., Zawoznik, M.S., Groppa, M.D., Benavides ,M.P .2012. Unravelling cadmium toxicity and tolerance in plants: insight into regulatory mechanisms. Environ. Exp. Bot. 83:33-46.

Gill, S.S., Tuteja, N. 2011. Cadmium stress tolerance in crop plants: probing the role of sulfur, Plant Signaling Behav. 6:215-222.

Hall, J . 2002. Cellular mechanisms for heavy metal detoxification and tolerance. J. exp. Bot. 53: 1-11.

Hsu ,Y.T., Kao, C.H .2004. Cadmium toxicity is reduced by nitric oxide in rice leaves. Plant Growth Regul. 42:227-238.

Kovacik, J., Klejdus, B., Hedbavny, J., Stork, F., Backor, M .2009. Comparison of cadmium and copper effect on phenolic metabolism, mineral nutrients and stress-related parameters in Matricaria chamomilla plants, Plant Soil. 320: 231-242.

Kovacik, J., Babula, P., Hedbavny, J., Klejdus, B.2014a. Hexavalent chromium damages chamomile plants by alteration of antioxidants and its uptake is prevented by calcium. J. Hazard. Mater. 273: $110-117$.

Kovacik, J., Babula, P., Klejdus, B., Hedbavny, J., Jarosova, M.2014b. Unexpected Behavior of Some Nitric Oxide Modulators under Cadmium Excess in Plant Tissue. PLoS ONE 9(3): e91685. 
Kovacik, J., Babula, P., Hedbavny, J., Krystofova, O., Provaznik, I.2015. Physiology and methodology of chromium toxicity using alga Scenedesmus quadricauda as model object. Chemosphere. 120: 23-30.

Lamattina, .L, Garcia-Mata, C., Graziano, M., Pagnussat, G.2003. Nitric oxide: the versatility of an extensive signal molecule. Annu Rev Plant Biol. 54:109-136.

Ma, J.F., Ueno, D., Zhao, F.J., McGrath, S.P. 2005. Subcellular localisation of $\mathrm{Cd}$ and $\mathrm{Zn}$ in the leaves of a Cd-hyperaccumulating ecotype of Thlaspi caerulescens. Planta. 220: 731-736.

Moreau, M., Lindermayr, C., Durner, J., Klessig, D. 2010. NO synthesis and signaling in plants-where do we stand? Physiologia Plantarum. 138:372-383.

Retamal-Salgado, J., Matus, I., Walter, I. , Hirzel, J. 2017. Absorption and distribution of cadmium of three maize hybrids in three environments.Journal of Soil Science and Plant Nutrition, 2017, 17 (2), 266-278

Saxena, I., Shekhawat, G.S. 2013. Nitric oxide (NO) in alleviation of heavy metal induced phytotoxicity and its role in protein nitration. Nitric Oxide. 32: $13-20$.

Schutzendubel, A., Polle, A .2002. Plant responses to abiotic stresses: heavy metal induced oxidative stress and protection by mycorrhization. J. Exp. Bot. 53 :1351-1365.

Singh, H.P., Batish, D.R., Kaur, G., Arora, K., Kohli, R.K .2008. Nitric oxide (as sodium nitroprusside) supplementation ameliorates Cd toxicity in hydroponically grown wheat roots. Environ Exp Bot. 63:158-167.

Singh, P.K., Tewari, R.K.2003. Cadmium toxicity induced changes in plant water relations and oxidative metabolism of Brassica juncea L. plants. J Environ Biol. 24:107-112.
Tezotto, T., Favarin, J.L., Azevedo, R.A., Alleoni, .LR.F., Mazzafera, P.2012. Coffee is highly tolerant to cadmium, nickel and zinc: plant and soil nutritional status, metal distribution and bean yield. Field Crop. Res. 125:25-34.

Valko, M., Leibfritz, D., Moncol, J., Cronin, M.T., Mazur, M., Telser, J.2007. Free radicals and antioxidants in normal physiological functions and human disease. Int. J. Biochem. Cell Biol. 39:44-84.

Verbruggen, N., Hermans, C., Schat, H.2009. Mechanisms to cope with arsenic or cadmium excess in plants, Curr. Opin. Plant Biol. 12:364-372.

Verma, K., Mehta, S.K., Shekhawat, G.S. 2013. Nitric oxide (NO) counteracts cadmium induced cytotoxic processes mediated by reactive oxygen species (ROS) in Brassica juncea: cross-talk between ROS, NO and antioxidant responses. Biometals. 26:255-269.

Wang, Q.H., Liang, X., Dong, Y.J., Xu, L.L., Zhang, X.W., Kong ,J., Liu, S .2013. Effects of exogenous salicylic acid and nitric oxide on physiological characteristics of perennial ryegrass under cadmium stress. J Plant Growth Regul. 32:721-731.

Wang, W.W., Bai, X.Y., Dong, Y.J., Chen, W.F., Song, Y.L., Tian, X.Y. 2016. Effects of application of exogenous $\mathrm{NO}$ on the physiological characteristics of perennial ryegrass grown in Cd-contaminated soil. Journal of Soil Science and Plant Nutrition 16 (3), 731-744.

Wendehenne, D., Pugin, A., Klessing, D.F., Durner, J. .2001. Nitric oxide: comparative synthesis and signaling in animal and plant cells. Trends Plant Sci. 6:177-186. 
Weigel, H.J., Jäger, H.J .1980. Subcellular distribution and chemical form of cadmium in bean plants. Plant Physiol. 65:480-482.

Xiong, J., An, L.Y., Lu, H., Zhu, C.2009. Exogenous nitric oxide enhances cadmium tolerance of rice by increasing pectin and hemicellulose contents in root cell wall. Planta. 230:755-765.
Xu, L.L., Dong, Y.J., Kong, J., Liu, S. 2014a. Effects of root and foliar applications of exogenous NO on alleviating cadmium toxicity in lettuce seedlings. Plant Growth Regul. 72 (1) :39-50.

Xu, W.F., Shi, W.M., Yan, F., Zhang, B., Liang, J.S. 2011. Mechanisms of cadmium detoxification in cattail (Typha angustifolia L.). Aquatic Botany 94:37-43. 